\section{The College Library}

The Librarian would like to thank those Members of the College who so very generously donated copies of their works to the College Library. Books have recently been received from the following:

Dr A. Bentovim Child Sexual Abuse in the Family and Related Papers

Dr A. Daniels Fool or Physician: Memoirs of $a$ Sceptical Doctor

Dr M. Faulk Basic Forensic Psychiatry

Professor H. Freeman The Treatment of Mental Disorders in the Community; The Future of Pharmacotherapy New Drug Delivery Systems

Dr J. Gold The Psychiatric Implications of Menstruation

Dr H. P. Greenberg Handbook of Neuropsychological Assessment

Dr N. Holden Examination Techniques in Psychiatry

Dr L. Iverson Cognitive Neurochemistry

Dr D. F. Klein Anxiety
Professor M. Lader The Patterns of Improvement in Depressed In-Patients

Professor W. A. Lishman Organic Psychiatry

Dr P. Lomas The Limits of Interpretation

Dr M. J. Pritchard Medicine and the Behavioural Sciences

Dr J. D. Pollitt Psychiatric Emergencies in Family Practice

Professor W. L. Rees A New Short Textbook of Psychiatry

Professor B. Sacks The Adolescent with Down's Syndrome

Professor A. C. P. Sims Symptoms of the Mind: An Introduction to Descriptive Psychopathology

Dr D. A. Spencer Report on Meanwood Park Hospital

Dr G. J. Taylor Psychosomatic Medicine and Contemporary Psychoanalysis

Dr C. Thompson The Origins of Modern Psychiatry

Dr M. R. Trimble Biological Psychiatry

\title{
Obituary
}

\section{Editor: Henry R. Rollin}

GHULAM ALI ASGHAR, Medical Director, Asghar Hospital, Karachi, Pakistan.

Dr Asghar died at the age of 75. He was a distinguished Pakistani psychiatrist and a Foundation Fellow of the College.

He was born on 16 July 1912 in a small village near Layalpur, Punjab, Pakistan. He was educated at a local school and subsequently graduated from Amritsar Medical School in India.

On leaving Medical School he joined the Railway Medical Services, but when World War II erupted he joined the Army Medical Service, achieving the rank of Captain. It was during a stay at an army camp at Ranchi, located near the mental hospital, that he started to take an interest in psychiatry. He subsequently joined the staff of Ranchi Mental Hospital and was later transferred to Lahore Mental Hospital.

He decided to further his studies in England and joined Dr Arthur Oldham's firm at Cane Hill Hospital, Coulsdon. He took a part in the establishment of an ECT unit and took a great interest in other physi- cal methods of treatment in psychiatry, including insulin therapy. He took part in a trial of the newly established phenothiazine, chlorpromazine (Largactil), and together with Dr William Sargant monitored the side effects of the drug to be seen in some patients exposed to direct sunlight.

On a second visit to England he obtained the DPM, after which he returned to resume charge as Physician Superintendent of Hyderabad Mental Hospital.

On leaving this hospital he went into private practice in Karachi and established his own private psychiatric hospital serving the local community and patients from all over Pakistan.

He held the posts of Associate Professor of Psychiatry at F.J. Medical School, Liquet Medical School and Dow Medical College Karachi. He was active in the Karachi Mental Health Foundation and was its Honorary Founder President and was an active and respected member of Pakistan Psychiatric Society. He welcomed the opportunity of attending 
WPA meetings and his autobiography, Sargazasht written in Urdu will inspire many a young doctor to take an interest in psychiatry and its practice in a region where $80 \%$ of the population still live in villages with just the basic necessities of life.

His gentle smile, Punjabi sense of humour and warm hospitality will be remembered by all his friends and family. He is survived by his two sons, a daughter and his second wife.

MFH

\section{ISABEL CATHERINE ARCHIBALD MOYES, Consultant Psychiatrist, The London Hospital (St Clement's), London E3}

During the course of her three years as Senior Lecturer in Psychogeriatrics at The London Hospital Medical College Isabel Moyes endeared herself to all who knew her. Her enthusiasm, warmth and genuine affection for her elderly patients and the team who served them made her a good clinician and she was untiring in her efforts to press for better services at a time of increasing stringency.

The only daughter of the late Professor James Greig, an electrical engineer, she was born in Edinburgh in 1932 and brought up in London, Birmingham and Scotland. She studied medicine at Oxford University qualifying in 1958 and moving to The University of St Andrews where she pursued an interest in the physiology and chemistry of amniotic fluid for which work she obtained her MSc in 1965.

It was during this time that she met and married $\mathrm{Dr}$ Richard Moyes, now Senior Lecturer in Chemistry at Hull University. They have three children; Caroline 24, Alastair 22, and Victoria 19 . The family moved to Hull in 1964 and Isabel entered psychiatry obtaining her DPM in 1968. In 1972 she was appointed consultant at Broadgate Hospital, North Humberside, and in the years which followed she became increasingly interested in the problems of the elderly, particularly in the differential diagnosis of depression and dementia. At the same time she continued research into the relation of plasma levels of antidepressants to clinical symptomatology. She pioneered the use of community psychiatric nurses in the psychogeriatrics field and initiated a travelling day hospital with enthusiastic support from the nursing team.

Isabel was an active member and, from 1983 , chairman of the executive committee of the burgeoning group for the Psychiatry of Old Age of the Royal College of Psychiatrists. She was elected to the fellowship of the College in 1980 after only seven years as a member.

A colleague on her team, at The London Hospital (St Clement's), writes of her "We remember her bubbly personality, direct manner and her impish sense of humour. Isabel, as consultant of the Elderly
Team, was steering us on a course of personalised, humanistic care for the elderly with so much conviction and enthusiasm that it was difficult not to be affected and equally inspired."

CMP

\section{DEREK MALCOLM RICKS, Consultant in \\ Paediatric Mental Handicap, Harper House Children's Service, Harper House, Hertfordshire}

Dr Derek Ricks died suddenly on 3 March 1988 at the age of 59.

Derek was educated at Willesden County Grammar School, where he gave early notice of his exceptional intellectual ability by being awarded a State Scholarship.

In 1952 he obtained a Bachelor of Arts degree with First Class Honours at University College, London, and proceeded with a postgraduate scholarship to write a thesis on 'Reasons for contrasts in town growth 1800-1950 in towns on the North West Periphery of London'. Research for this involved a detailed knowledge of the geography of North London, which he acquired by cycling along each road and path in the area. This information was to stand him in good stead in future years when his ability to negotiate traffic jams using his own private routes became the envy of his colleagues.

Following two years' lectureship in the Arts Facility of University College, London, Derek changed direction and commenced his medical education, qualifying from University College Hospital in 1961 .

His fascination with the working of the human mind and the use of language directed him into a career in psychiatry, and after appointments at University College, The Maudsley, and Cell Barnes Hospitals he was appointed Consultant Psychiatrist at Harperbury Hospital in 1970. This was followed in the early 1970s by appointments as Honorary Consultant Psychiatrist at Great Ormond Street, and as Honorary Consultant in Paediatric Mental Handicap in the Department of Paediatrics and Child Psychiatry at University College Hospital, London. In 1972 he was awarded a doctorate by the University of London for his thesis 'The beginning of verbal communication in normal and autistic children'.

Derek's special concern was with child handicap and he became a pioneer in the care and treatment of children with mental handicap. His nationally acclaimed knowledge of his specialty led to his appointment as a member of the Government Committee of Enquiry into Mental Handicap Nursing and Care (The Jay Committee) in 1975. In 1977 he was elected a Member of the British Paediatric Association and in 1981 became an Honorary 